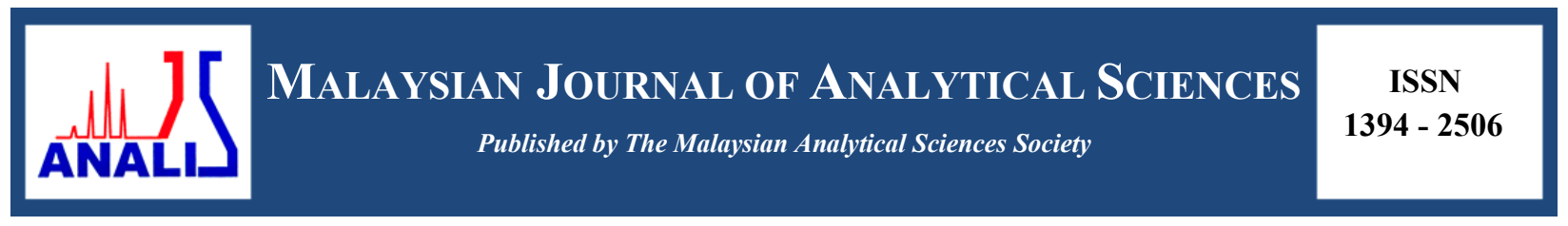

\title{
ROLE OF ACTIVE CHROMIUM SPECIES ON DIFFERENT SUPPORT FOR DEHYDROGENATION OF PROPANE
}

\author{
(Peranan Spesies Kromium Aktif pada Penyokong yang Berbeza dalam Tindak balas \\ Penyahhidrogenan Gas Propana)
}

\author{
Wan Nor Roslam Wan Isahak ${ }^{1,2}$, Zatil Amali Che Ramli ${ }^{2}$, Ibdal Satar ${ }^{2}$, Mohamed Wahab Mohamed Hisham $^{3}$, \\ Mohd Ambar Yarmo ${ }^{3}$ \\ ${ }^{I}$ Department of Chemical and Process Engineering, Faculty of Engineering and Built Environment \\ ${ }^{2}$ Fuel Cell Institute \\ ${ }^{3}$ School of Chemical Sciences and Food Technology, Faculty of Science and Technology \\ Universiti Kebangsaan Malaysia, 43600 UKM Bangi, Selangor, Malaysia \\ *Corresponding author: wannorroslam@ukm.edu.my
}

Received: 21 October 2015; Accepted: 14 June 2016

\begin{abstract}
Dehydrogenation of propane (DHP) was studied over a series of $\mathrm{Cr}_{2} \mathrm{O}_{3}-\mathrm{Al}_{2} \mathrm{O}_{3}$ and $\mathrm{Cr}_{2} \mathrm{O}_{3}-\mathrm{SiO}_{2}$ catalysts, prepared by incipient wetness impregnation and sol gel (SG) method, respectively, to gain a better understanding of the nature and distribution of chromium (Cr) species and their catalytic function. To this end, the catalysts were characterized by $\mathrm{N}_{2}$-physisorption and $\mathrm{X}$-ray diffraction (XRD). $\mathrm{N}_{2}$-physisorption analysis of $\mathrm{Cr}_{2} \mathrm{O}_{3}-\mathrm{SiO}_{2}$ showed the relatively higher surface area of $391.1 \mathrm{~m}^{2} / \mathrm{g}$, compared with $\mathrm{Cr}_{2} \mathrm{O}_{3}-\mathrm{Al}_{2} \mathrm{O}_{3}$ of $224.3 \mathrm{~m}^{2} / \mathrm{g}$. The combination method of sol gel and sonothermal also produced smaller particles size of catalyst with higher microporosity of $23.5 \%$ and smaller pores size of $6 \mathrm{~nm}$. The good surface properties of $\mathrm{Cr}_{2} \mathrm{O}_{3}-\mathrm{SiO}_{2}$ enabled the high conversion of propane of $55 \%$ at $550{ }^{\circ} \mathrm{C}$. At higher temperature of $600{ }^{\circ} \mathrm{C}$, the $\mathrm{Cr}$ species might be reduced into lower oxidation state and inhibit the catalytic behavior to produce hydrogen.
\end{abstract}

Keywords: chromium (II) oxide, thermodynamic consideration, sonothermal, catalytic behavior, hydrogen energy

\begin{abstract}
Abstrak
Tindak balas penyah-hidrogenan gas propana (DPP) telah dikaji menggunakan beberapa siri mangkin $\mathrm{Cr}_{2} \mathrm{O}_{3}-\mathrm{Al}_{2} \mathrm{O}_{3}$ dan $\mathrm{Cr}_{2} \mathrm{O}_{3}$ $\mathrm{SiO}_{2}$ yang dihasilkan melalui kaedah impregnasi basah dan sol gel (SG) method, untuk memahami sifat dan serakan spesies logam $\mathrm{Cr}$ dan fungsi pemangkinannya. Dalam kajian ini, mangkin diciri menggunakan kaedah jerapan gas $\mathrm{N}_{2}$ dan pembelauan sinar X (XRD). Analisis jerapan $\mathrm{N}_{2}$ bagi mangkin $\mathrm{Cr}_{2} \mathrm{O}_{3}-\mathrm{SiO}_{2}$ menunjukkan ia mempunyai luas permukaan yang paling tinggi sebanyak $391.1 \mathrm{~m}^{2} / \mathrm{g}$, berbanding mangkin $\mathrm{Cr}_{2} \mathrm{O}_{3}-\mathrm{Al}_{2} \mathrm{O}_{3}$ sebanyak $224.3 \mathrm{~m}^{2} / \mathrm{g}$. Kombinasi kaedah sol gel (SG) dan sonotermal menghasilkan mangkin yang bersaiz lebih kecil dengan keporosan mikro sebanyak $23.5 \%$ dan saiz liang sebanyak 6 nm. Ciri-ciri permukaan yang baik ditunjukkan oleh mangkin $\mathrm{Cr}_{2} \mathrm{O}_{3}-\mathrm{SiO}_{2}$ menyumbang kepada aktiviti tindak balas yang baik dengan peratus penukaran propana yang tinggi sebanyak $55 \%$ pada suhu $550{ }^{\circ} \mathrm{C}$. Pada suhu tindak balas $600{ }^{\circ} \mathrm{C}$ pula, spesies logam $\mathrm{Cr}$ boleh terturun kepada keadaan pengoksidaan yang lebih rendah dan merencat tindak balas pemangkin bagi menghasilkan gas hidrogen sebagai produk utama.
\end{abstract}

Kata kunci: kromium (II) oksida, pendekatan termodinamik, sonotermal, sifat pemangkinan, tenaga hidrogen 


\section{Wan Nor Roslam et al: ROLE OF ACTIVE CHROMIUM SPECIES ON DIFFERENT SUPPORT FOR \\ DEHYDROGENATION OF PROPANE}

\section{Introduction}

Propane is produced as a by-product of two other processes, natural gas processing and petroleum refining. The processing of natural gas involves removal of butane, propane, and large amounts of ethane from the raw gas, in order to prevent condensation of these volatiles in natural gas pipelines. Commonly, the dehydrogenation of propane can produce propene and hydrogen as a greener and future fuel sources and carried higher energy [1]. The reaction conditions play a major role to direct the reaction route and selected products. It is possible to produce hydrogen by catalytic dehydrogenation of propane, according to the following reaction (equation 1 and 2):

$$
\begin{array}{ll}
\mathrm{C}_{3} \mathrm{H}_{8} \rightarrow \mathrm{C}_{3} \mathrm{H}_{6}+\mathrm{H}_{2} & \Delta \mathrm{H}^{\mathrm{o}}=124{\mathrm{~kJ} . \mathrm{mol}^{-1}}^{-1} \\
\mathrm{C}_{3} \mathrm{H}_{8}(\mathrm{~g}) \rightarrow \mathrm{C}(\mathrm{s})+\mathrm{C}_{2} \mathrm{H}_{6}(\mathrm{~g})+\mathrm{H}_{2}(\mathrm{~g}) & \Delta \mathrm{H}^{\mathrm{o}}=19.1{\mathrm{~kJ} . \mathrm{mol}^{-1}}^{-1}
\end{array}
$$

However, this reaction cannot be carried out easily due to its strong endothermicity $\left(\Delta \mathrm{H}_{\mathrm{r}}^{\mathrm{o}}=124 \mathrm{~kJ} . \mathrm{mol}^{-1}\right)$. Sattler et al. [2] were reviewed various type of catalytic dehydrogenation of light alkanes into other products namely methane, hydrogen, ethane and other series of alkenes. Several type of catalyst have been studied by researchers such as platinum-based, gallium oxide-based and vanadium oxide-based catalysts. In other work, Lee et al. [3] was reported the $\mathrm{Sn}$ addition to the $\mathrm{Pt}_{0.5} / \theta-\mathrm{Al}_{2} \mathrm{O}_{3}$ catalyst can decreased the cracking products of $\mathrm{C}_{1}-\mathrm{C}_{3}$ and increase the stability and olefin selectivity.

This paper was focused on the hydrogen formation by catalytic dehydrogenation of propane. The effect of chromium species was also studied. The pure hydrogen can be produced from this reaction.

\section{Thermodynamic consideration}

\section{Materials and Methods}

The catalyst selection was performed using a simple thermodynamic approach based on thermodynamic data. Several pyrolysis routes have been selected to study the possibility. For example, the propane gas can be pyrolyzed into methane and hydrogen. There was some possible route for propane dehydrogenation reaction (equation 3 - 5).

$$
\begin{aligned}
& \mathrm{C}_{3} \mathrm{H}_{8} \rightarrow \mathrm{C}_{3} \mathrm{H}_{6}+\mathrm{H}_{2} \\
& \mathrm{C}_{3} \mathrm{H}_{8} \rightarrow 2 \mathrm{C}+\mathrm{CH}_{4}+2 \mathrm{H}_{2} \\
& \mathrm{C}_{3} \mathrm{H}_{8} \rightarrow 3 \mathrm{C}+4 \mathrm{H}_{2}
\end{aligned}
$$

\section{Synthesis of catalyst}

The catalyst $15 \% \mathrm{Cr}_{2} \mathrm{O}_{3} / \gamma-\mathrm{Al}_{2} \mathrm{O}_{3}$ was synthesized by using the wet impregnation method. $3.95 \mathrm{~g}$ of $\mathrm{Cr}\left(\mathrm{NO}_{2}\right)_{3} \cdot 9 \mathrm{H}_{2} \mathrm{O}$ was dissolved in $10 \mathrm{ml}$ of distilled water. Then, $8.5 \mathrm{~g}$ of $\gamma-\mathrm{Al}_{2} \mathrm{O}_{3}$ was added into the solution and stir for 1 hour. The mixed sample was introduced to ultrasonicator for 10 minutes. The sample was dried at $110{ }^{\circ} \mathrm{C}$ and calcine at 400 ${ }^{\circ} \mathrm{C}$ for 3 hours before the catalyst is ready to test in reaction.

The $15 \% \mathrm{Cr}_{2} \mathrm{O}_{3} / \mathrm{SiO}_{2}$-sol gel (SG) was prepared by sol gel method by mixing the tetraethyl orthosilicate (TEOS) and ethanol with molar ratio of 1:1 to obtain a sol gel precursor solution. Then, several amount of $\mathrm{Cr}\left(\mathrm{NO}_{2}\right)_{3} \cdot 9 \mathrm{H}_{2} \mathrm{O}$ was dissolved in distilled water followed by some nitric acid addition. Both mixtures were stirred by vigorous magnetic stirring separately at room temperature until the $\mathrm{pH} 2$ was observed. The solution was lifted for 24 hours until gelation is complete. The samples were dried at $110^{\circ} \mathrm{C}$ and calcined at $400{ }^{\circ} \mathrm{C}$ for 3 hours before ready for use.

\section{Characterization of catalyst}

Nitrogen adsorption at 77K (liquid nitrogen) was conducted using a Micromeritics ASAP 2010 instrument to obtain the adsorption isotherm of each sample. The Brunauer-Emmett-Teller (BET) surface area, micropore volume and micropore area were calculated from the isotherms. Before analysis was conducted, the samples were degassed at $350{ }^{\circ} \mathrm{C}$ for 6 hours. The crystallinity analyses of the samples were performed using a Bruker DB-Advance X-ray Diffractometer (XRD), Germany. The analyses were performed with 1-g samples, employing $\mathrm{Cu} \mathrm{K} \alpha$ radiation at $2 \theta$ ranging from $10^{\circ}$ to $80^{\circ}$. 


\section{Propane pyrolysis reaction}

The propane pyrolysis was conducted using fluidized bed reactor under propane gas flows at ranging of $30-70$ $\mathrm{mL} / \mathrm{min}$. The output gas was analyzed using GC-FID.

\section{Results and Discussion}

\section{Thermodynamic consideration}

There were several possible reactions might be occurred during the pyrolysis of propane as showed in Table 1 . The reactions 3 to 5 (R1-R5) are very favorable at low temperature. However, the possible R1 and R2 is need high temperature to occur (more than $972 \mathrm{k}$ ). Theoretically, R3 to R5 can occur at relatively low ranging temperature of $180-402 \mathrm{~K}$. However, the presence of energy barrier or high activation energy during the reaction contributed the sum of error around $30 \mathrm{~kJ} / \mathrm{mol}^{-1}$ or $500 \mathrm{~K}$. It was noted that the tendency to produce carbon during propane pyrolysis is high in the present of metal oxide catalyst $[4,5]$.

Table 1. Thermodynamics data of possible reactions for propane pyrolysis

\begin{tabular}{|c|c|c|c|c|c|}
\hline Reaction Involved & $\begin{array}{c}\Delta \mathbf{H} \\
\left(\mathbf{K j} \cdot \mathbf{M o l}^{-1}\right)\end{array}$ & $\begin{array}{c}\Delta \mathrm{S} \\
\left(\mathrm{J} \cdot \mathrm{Mol}^{-1} \cdot \mathbf{K}^{-1}\right)\end{array}$ & $\begin{array}{c}\Delta \mathrm{G} \\
\left(\mathrm{Kj} \cdot \mathrm{Mol}^{-1}\right)\end{array}$ & $\begin{array}{c}\mathbf{T} \\
(\mathbf{K})\end{array}$ & Reaction Possibility \\
\hline $\begin{array}{l}\mathrm{C}_{3} \mathrm{H}_{6}(\mathrm{~g}) \rightarrow \mathrm{C}_{3} \mathrm{H}_{6}(\mathrm{~g})+ \\
\mathrm{H}_{2}(\mathrm{~g}) \mathbf{R} \mathbf{1}\end{array}$ & 124.2 & 127.8 & 0 & 972 & $\begin{array}{l}\text { Favourable at high } \\
\text { temperature }\end{array}$ \\
\hline $\begin{array}{l}\mathrm{C}_{3} \mathrm{H}_{8}(\mathrm{~g}) \rightarrow \mathrm{C}_{2} \mathrm{H}_{2}(\mathrm{~g})+ \\
\mathrm{CH}_{4}(\mathrm{~g})+\mathrm{H}_{2}(\mathrm{~g}) \mathbf{R} \mathbf{2}\end{array}$ & -197.7 & -153.8 & -5 & 1253 & $\begin{array}{l}\text { Favourable at very } \\
\text { high temperature }\end{array}$ \\
\hline $\begin{array}{l}\mathrm{C}_{3} \mathrm{H}_{8}(\mathrm{~g}) \rightarrow \mathrm{C}(\mathrm{s})+ \\
\mathrm{C}_{2} \mathrm{H}_{6}(\mathrm{~g})+\mathrm{H}_{2}(\mathrm{~g}) \mathbf{R} \mathbf{3}\end{array}$ & 19.1 & 84.7 & -5 & 285 & Favourable \\
\hline $\begin{array}{l}\mathrm{C}_{3} \mathrm{H}_{8}(\mathrm{~g}) \rightarrow 2 \mathrm{C}(\mathrm{s})+ \\
\mathrm{CH}_{4}(\mathrm{~g})+2 \mathrm{H}_{2}(\mathrm{~g}) \mathbf{R} \mathbf{4}\end{array}$ & 29.0 & 189.3 & -5 & 180 & Favourable \\
\hline $\begin{array}{l}\mathrm{C}_{3} \mathrm{H}_{8}(\mathrm{~g}) \rightarrow 3 \mathrm{C}(\mathrm{s})+ \\
4 \mathrm{H}_{2}(\mathrm{~g}) \mathbf{R 5}\end{array}$ & 103.8 & 270.9 & -5 & 402 & Favourable \\
\hline
\end{tabular}

\section{Catalysts surface properties}

Figure 1 showed the adsorption-desorption isotherm of the fresh support and modified catalyst. The fresh $\mathrm{SiO}_{2}$ (Figure 1 (a)) and $\mathrm{Al}_{2} \mathrm{O}_{3}$ (Figure 1 (b)) showed the adsorption isotherms type II and IV, respectively. However, the dispersion of $\mathrm{Cr}_{2} \mathrm{O}_{3}$ on $\mathrm{SiO}_{2}$ (in Figure 1 (c)) was changed the adsorption isotherm into type I. Type I isotherms are observed for the adsorption of gases on microporous solids whose pore sizes are not much larger than the molecular diameter of the adsorbate. This property can bring forward the solid-gases reaction which is most of the reaction occurs in pores and surfaces [6]. On the other hand, the $\mathrm{Cr}_{2} \mathrm{O}_{3} / \mathrm{SiO}_{2}$ catalyst (Figure 1 (d)) showed the hysteresis type IV represented to slit-shaped pores with uniform in size [7]. This type of hysteresis can maximize the reactant adsorption during reaction and desorbed the products easily. Table 2 showed the better surface properties of $\mathrm{Cr}_{2} \mathrm{O}_{3} / \mathrm{SiO}_{2}$ with higher surface area and microporosity of $391.1 \mathrm{~m}^{2} / \mathrm{g}$ and $23.5 \%$, respectively. The higher surface area with maximum metal oxide dispersion would lead the higher active sites and subsequently contribute to good catalytic activity. 

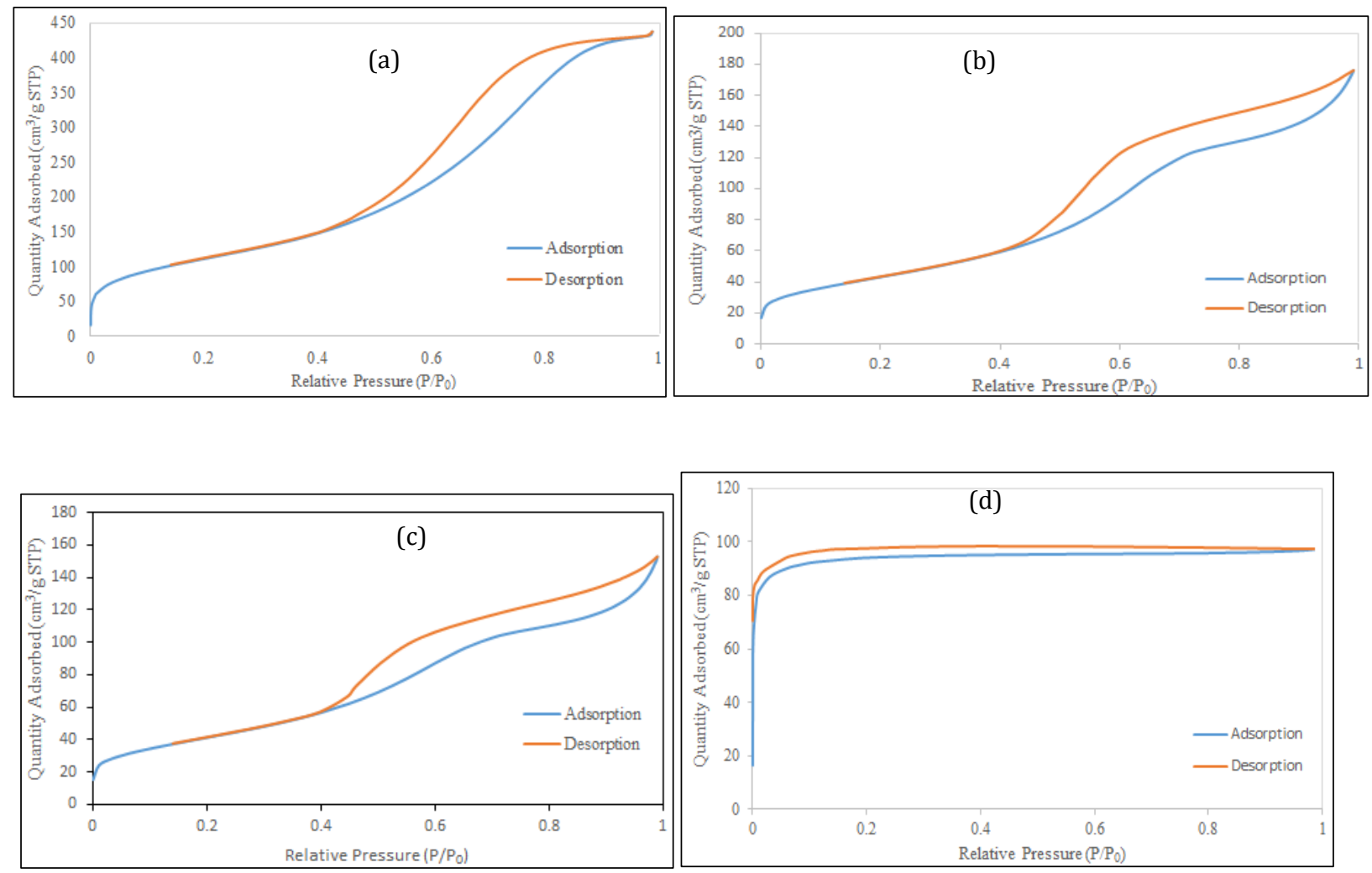

Figure 1. The isotherms of a) $\mathrm{SiO}_{2}$, b) $\mathrm{Al}_{2} \mathrm{O}_{3}$, c) $\mathrm{Cr}_{2} \mathrm{O}_{3}-\mathrm{Al}_{2} \mathrm{O}_{3}$ and d) $\mathrm{Cr}_{2} \mathrm{O}_{3}-\mathrm{SiO}_{2} \mathrm{SG}$

Table 2. The physical properties of catalysts

\begin{tabular}{lccc}
\hline Selected Catalysts & Microporosity $(\%)$ & Pores Size $(\mathbf{n m})$ & Surface area $\left(\mathbf{m}^{2} / \mathbf{g}\right)$ \\
\hline $\mathrm{SiO}_{2}$ & 4.8 & 6.83 & 391.1 \\
$\mathrm{Al}_{2} \mathrm{O}_{3}$ & 1.3 & 6.85 & 154.4 \\
$\mathrm{Cr}_{2} \mathrm{O}_{3}-\mathrm{Al}_{2} \mathrm{O}_{3}$ & 1.4 & 6.02 & 308.8 \\
$\mathrm{Cr}_{2} \mathrm{O}_{3}-\mathrm{SiO}_{2}$ & 23.5 & 6.19 & 224.3 \\
\hline
\end{tabular}

\section{Crystallinity of catalyst}

XRD analyses were performed for the $\mathrm{Cr}_{2} \mathrm{O}_{3} / \mathrm{Al}_{2} \mathrm{O}_{3}, \mathrm{Cr}_{2} \mathrm{O}_{3} / \mathrm{SiO}_{2}, \mathrm{SiO}_{2}$ and $\mathrm{Al}_{2} \mathrm{O}_{3}$ as a support. Figure 2 (a) and 2 (b) showed the XRD patterns for semicrystalline $\mathrm{SiO}_{2}$ and crystalline $\mathrm{Al}_{2} \mathrm{O}_{3}$, respectively. Figure 2(c) showed the low intensity of $\mathrm{Cr}_{2} \mathrm{O}_{3}$ phase which detected at $34.8^{\circ}$ and $54.4^{\circ}$ with rhombohedral lattice system and the diffraction data match very well with JCPDS card of $\mathrm{Cr}_{2} \mathrm{O}_{3}$ (JCPDS 70-3765). No $\mathrm{CrO}_{2}$ phase was detected in this catalyst. The $\mathrm{Cr}_{2} \mathrm{O}_{3} / \mathrm{SiO}_{2}$ catalyst (Figure 2 (d)) showed three phases of $\mathrm{Cr}_{2} \mathrm{O}_{3}$ at $32.6^{\circ}, 34.7^{\circ}$ and $54.3^{\circ}$ with rhombohedral lattice system. The single phase of $\mathrm{CrO}_{2}$ was detected at $64.1^{\circ}$ with orthorhombic lattice system and the diffraction data match very well with the JCPDS card of $\mathrm{CrO}_{2}$ (JCPDS 75-7969). The high oxygen level of $\mathrm{CrO}_{2}$ phase can accelerate the propane cracking into hydrogen, propene, methane and carbon deposition [8]. After reaction, the graphite phase was detected in the catalyst due to carbon deposition as one of the product of the reaction at relatively high temperature. Besides, the $\mathrm{Cr}(\mathrm{IV})$ was fully reduced into $\mathrm{Cr}(\mathrm{III})$ due to high temperature reaction of $600{ }^{\circ} \mathrm{C}$. 


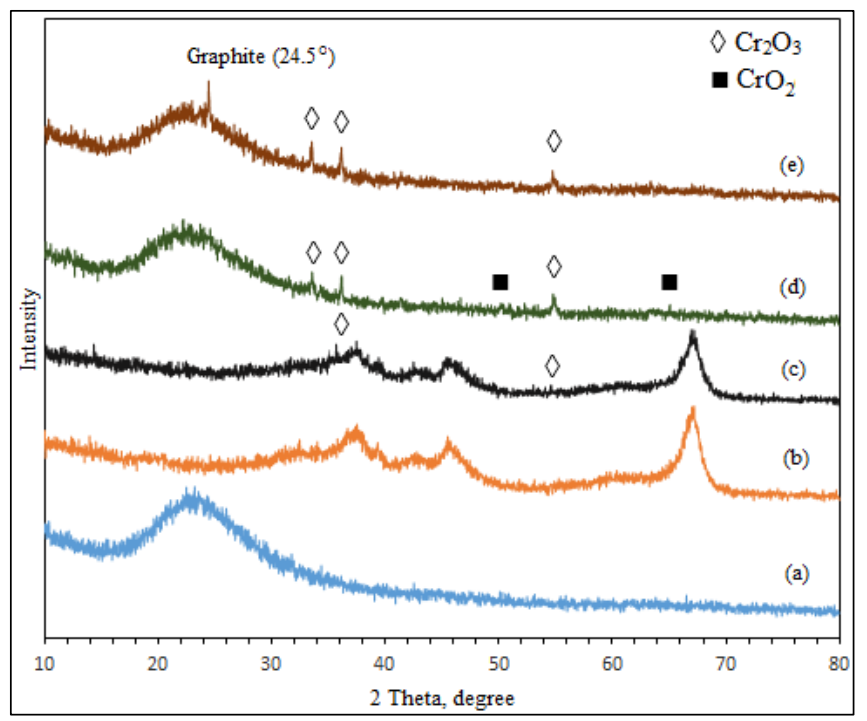

Figure 2. XRD diffractogram of (a) fresh $\mathrm{SiO}_{2}$, (b) fresh $\mathrm{Al}_{2} \mathrm{O}_{3}$, (c) $15 \% \mathrm{Cr}_{2} \mathrm{O}_{3} / \mathrm{Al}_{2} \mathrm{O}_{3}$, (d) $15 \% \mathrm{Cr}_{2} \mathrm{O}_{3} / \mathrm{SiO}_{2}$ and (e) $15 \% \mathrm{Cr}_{2} \mathrm{O}_{3} / \mathrm{SiO}_{2}$ after reaction

\section{Catalytic performances}

The pyrolysis reaction of propane gas was studied based on several parameters such as the effect of reaction temperature, reactant flowrate, reaction time and catalysts type. This reaction was performed in the range of temperature of $450-600{ }^{\circ} \mathrm{C}$. The range was selected by calculation of thermodynamic data which was favorable to occur. Figure 3 showed the effect of reaction temperature on propane pyrolysis into hydrogen and other hydrocarbon or carbon due to highly dispersion of $\mathrm{Cr}$ species on $\mathrm{SiO}_{2}$ surfaces. However, at $600{ }^{\circ} \mathrm{C}$, the propane conversion was relatively decreases due to $\mathrm{Cr}_{2} \mathrm{O}_{3}$ fully converted to $\mathrm{CrO}_{2}$ which decrease the catalyst activity of dehydration reaction with $\mathrm{C}_{3} \mathrm{H}_{6}$ and $\mathrm{H}_{2}$ are dominant products. Figure 4 showed the effect of residence time to propane conversion. The residence time is depended to the flowrate of the reactant which reacted to the catalyst. In this reaction, it was noted that higher residence time of 30 seconds gave the longer time for reaction to be occurred and achieved the completion.

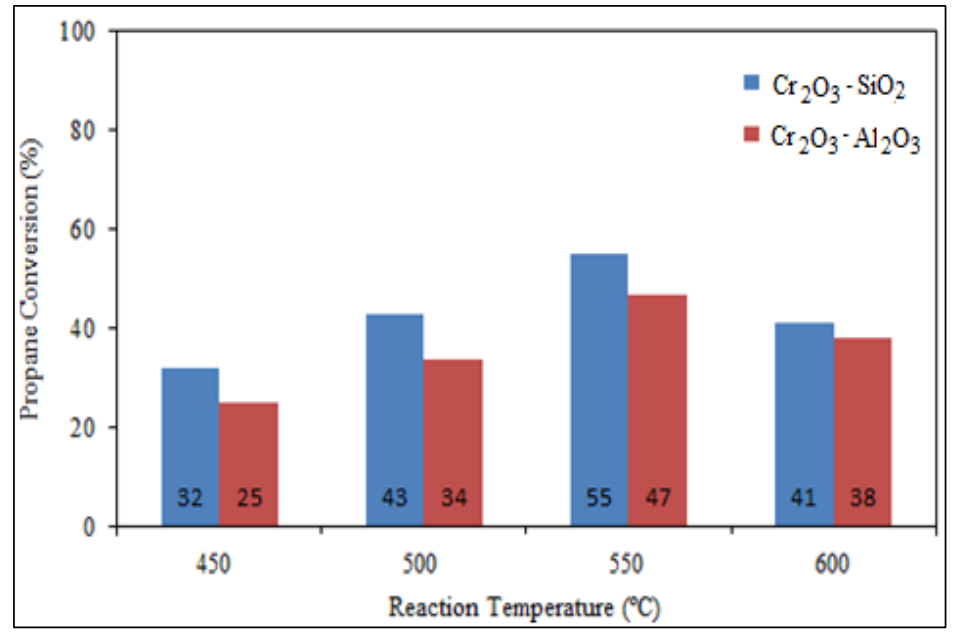

Figure 3. Effect of reaction temperature of (a) $\mathrm{Cr}_{2} \mathrm{O}_{3} / \mathrm{SiO}_{2} \mathrm{SG}$ and (b) $\mathrm{Cr}_{2} \mathrm{O}_{3} / \mathrm{Al}_{2} \mathrm{O}_{3}$ (Reaction carried out at flowrate of $60 \mathrm{~mL} / \mathrm{min}$ ) 


\section{Wan Nor Roslam et al: ROLE OF ACTIVE CHROMIUM SPECIES ON DIFFERENT SUPPORT FOR \\ DEHYDROGENATION OF PROPANE}

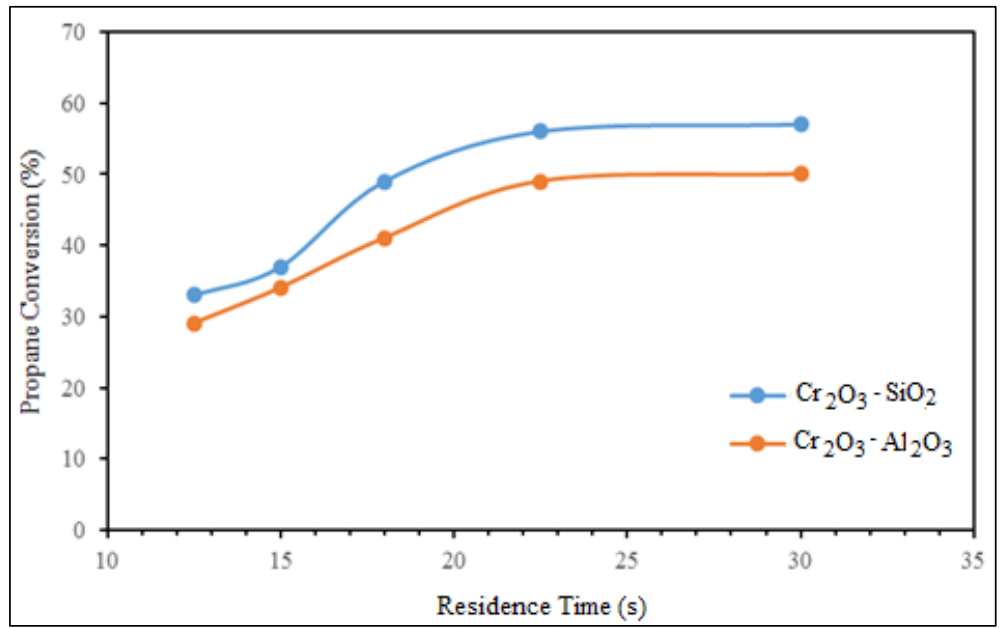

Figure 4. Effect of residence time of the reaction on $\mathrm{H}_{2}$ production for (a) $\mathrm{Cr}_{2} \mathrm{O}_{3}-\mathrm{Al}_{2} \mathrm{O}_{3}$ and (b) $\mathrm{Cr}_{2} \mathrm{O}_{3}-\mathrm{SiO}_{2} \mathrm{SG}$ (Reaction carried out at $550^{\circ} \mathrm{C}$ )

In Figure 5, at different reaction temperature, the $\mathrm{Cr}_{2} \mathrm{O}_{3}-\mathrm{SiO}_{2} \mathrm{SG}$ showed a series of products. At $550{ }^{\circ} \mathrm{C}$, the hydrogen is a major product followed by carbon deposition and $\mathrm{C}_{3} \mathrm{H}_{6}$ formation. However, at $600{ }^{\circ} \mathrm{C}$, the propene is significantly increased. It was noted that the high energy supply can bring forward the reaction route which produced hydrogen and propene as major products [3].

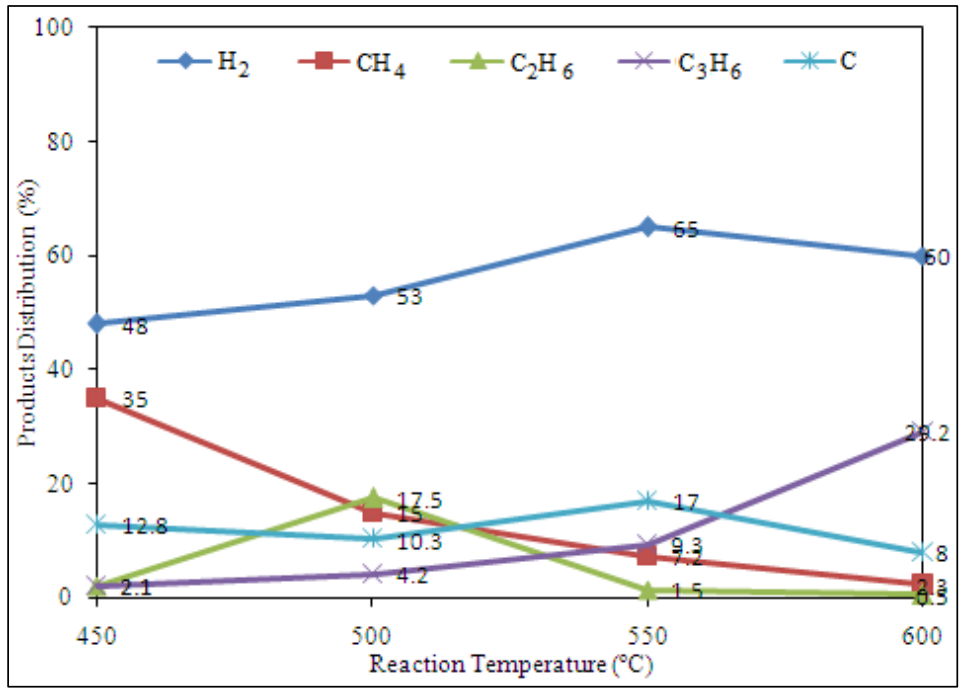

Figure 5. The products distribution from propane pyrolysis using $\mathrm{Cr}_{2} \mathrm{O}_{3}-\mathrm{SiO}_{2} \mathrm{SG}$ at optimum condition (Reaction was carried out at flowrate of $60 \mathrm{~mL} / \mathrm{min}$ )

\section{Proposed mechanism}

Thermodynamics theory approach can be used for evaluation the potential of metal oxide (MO) as catalyst in propane pyrolysis process. Theoretically, the breaking of hydrogen chain from carbon can easier occur if the formation of the new bond between MO and carbon is stronger. The bond between the carbon and MO known as 
physical interaction (van der wall bond), where the interaction is weak, but due to the effects of temperature, the heavier atoms (i.e., carbon and MO) tends easier to form a slightly stronger bonds than lighter atoms (i.e., hydrogen), consequently, the hydrogen bonds in the carbon is easier to break at lower temperatures. Thus, the catalyst material is expected to help increase the rate of hydrogen production and reduces the reaction temperature. The reaction mechanism between the MO with propane can be described in several possible routes as showed in Scheme 1.
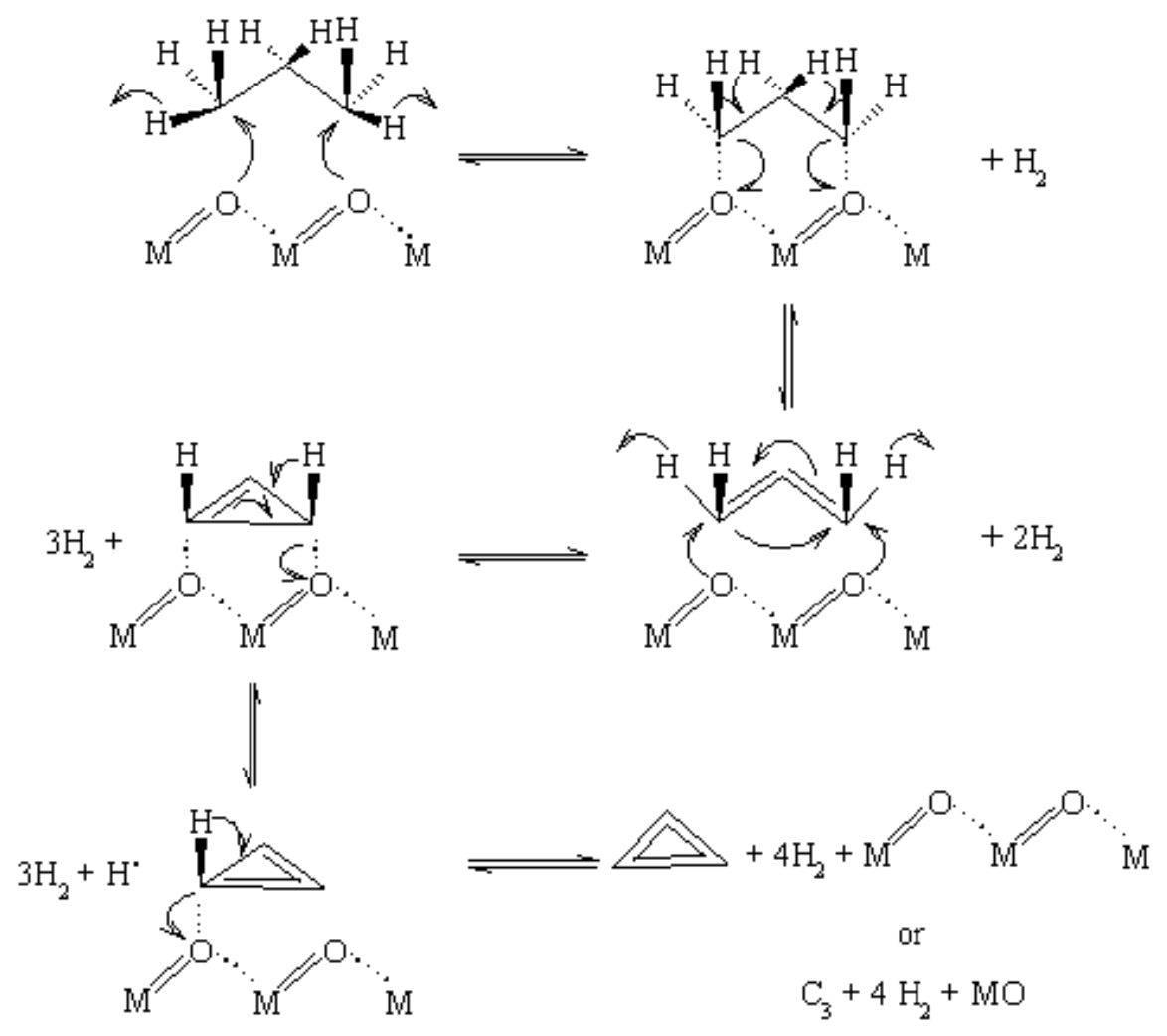

Scheme 1. Proposed mechanism of propane dehydrogenation over metal oxide catalyst

A thermodynamic calculation to illustrate that the mechanism (1) may only occur at high temperatures $(\approx 400 \mathrm{~K})$ due to the entropy of the reaction is very high $[9,10]$. This due to the process of acquiring $C$ is through the chain termination mechanism of double or triple bonds of $\mathrm{C}$. In this case, all of the hydrogen atom consist of propane has been transformed into four moles of $\mathrm{H}_{2}$ molecules and created a very stable double or triple bond of carbon which required a relatively high energy to dissociate. However, this mechanism just a form that is closest to clarify the possibility of the mechanism due to this mechanism is very complex which involves the variety of free radicals [11].

\section{Conclusion}

Hydrogen as a green fuel was successfully produce by dehydrogenation of propane in the presence of Cr-based catalyst. Thermodynamic calculation showed the feasibility of propane pysolysis into several products such as hydrogen, methane, propene and carbon depends on the reaction temperature. $\mathrm{The} \mathrm{Cr}_{2} \mathrm{O}_{3} / \mathrm{SiO}_{2}$ catalyst showed the better surface properties with high surface area of $393.1 \mathrm{~m}^{2} / \mathrm{g}$, microporosity of $23.5 \%$ and slit-shaped micropores. These properties were contributed to the higher propane conversion of due to high catalytic and gas adsorption ability. At $550{ }^{\circ} \mathrm{C}$, the hydrogen, $\mathrm{C}_{3} \mathrm{H}_{6}$ and carbon were dominant products with $55 \%$ of propane conversion. However, in long period, the high carbon deposition can deactivate the catalyst by covering the pores and surface and reduce the selectivity to hydrogen as a major product. 


\section{Wan Nor Roslam et al: ROLE OF ACTIVE CHROMIUM SPECIES ON DIFFERENT SUPPORT FOR \\ DEHYDROGENATION OF PROPANE}

\section{Acknowledgement}

The authors wish to thank Universiti Kebangsaan Malaysia (UKM) for funding this project under research grant, DIP-2016-010, FRGS/1/2015/SG01/UKM/02/2 and DPP-FKAB-2015 and the Centre of Research and Innovation Management (CRIM) UKM for the use of the instruments.

\section{References}

1. Caspary, K. J., Gehrke, H., Heinritz-Adrian, M. and Schwefer, M. (2008). Handbook of heterogeneous catalysis. Chapter 14: Dehydrogenation of alkanes. John Wiley \& Sons.

2. Sattler, J. J. H. B., Ruiz-Martinez, J., Santillan-Jimenez, E. and Weckhuysen, B. M. (2014). Catalytic dehydrogenation of light alkanes on metals and metal oxides. Chemical Reviews, 114 (20): 10613 -10653.

3. Lee, M-H., Nagaraja, B. M., Lee, K. Y. and Jung, K. D. (2014). Dehydrogenation of alkane to light olefin over $\mathrm{PtSn} / \mathrm{Al}_{2} \mathrm{O}_{3}$ catalyst: Effects of Sn loading. Catalysis Today, 232: $53-62$.

4. Wagman, D. D., Evans, W. H., Parker, V. B., Schumm, R. H., Halow, I., Bailey, S. M., Churney, K. L. and Nutall, R. L. (1989). The NBS tables of chemical thermodynamic properties selected values for inorganic and C1 and C2 organic substance in SI units. Journal of Physical Chemistry Reference Data, 11 (2): 1807.

5. Isahak, W. N. R. W., Ramli, Z. A. C., Ismail, M. W., Ismail, K., Yusop, R. M., Hisham, M. W. M. and Yarmo, M. A. (2013). Adsorption-desorption of $\mathrm{CO}_{2}$ on different type of copper oxides surfaces: Physical and chemical attractions studies. Journal of $\mathrm{CO}_{2}$ Utilization, 2: 8 - 15.

6. Brunauer, S., Emmett, P. H. and Teller, E. (1938). Adsorption of gasses in multimolecular layers. Journal of the American Chemical Society, 60: 309 - 316.

7. Rouquerol, J., Avnir, D., Fairbridge, C. W., Everett, D. H., Haynes, J. H., Pernicone, N., Ramsay, J. D. F., Sing, K. S. W. and Unger, K. K. (1994). IUPAC Recommendations for the characterization of porous solids. Pure and Applied Chemistry, 66: 1739 - 1758.

8. Kumar, M. S., Hammer, N., Rønning, M., Holmen, A., Chena, D., Walmsley, J. C. and Øye, G. (2009). The nature of active chromium species in Cr-catalysts for dehydrogenation of propane: New insights by a comprehensive spectroscopic study. Journal of Catalysis, 261 (1): $116-128$.

9. Karapet'yants, M. K. and Karapet'yants, M. L. (1970). Thermodynamic constants of inorganic and organic compounds. Ann Arbor-Humphrey Science Publishers.

10. Zeng, G., Tian, Y. and Li, Y. (2010). Thermodynamic analysis of hydrogen production for fuel cell via oxidative steam reforming of propane. International Journal of Hydrogen Energy, 35 (13): 6726 -6737.

11. Albright, L. F., Crynes, B. L. and Corcoran, W. H. (1983). Pyrolysis: Theory and industrial practice New York: Academic Press. 